新規抗血小板薬 Ethyl 2-[4,5-bis (4-methoxyphenyl) thiazol-2-yl]

pyrrol-1-ylacetate (KBT-3022) のマウスにおける

連続投与時の吸収, 分布, 排泄抢よび薬物代謝酵素系への影響

中田雄一郎・藤川 真章 - 粟田 則男 - 畔取 政行*

荒川 勝雅 $*$ 市毛 一美**・堀 勝行**

\title{
Absorption, Distribution, Excretion and Effects on Drug Metabolizing Enzyme Activities of a New Antiplatelet Drug, Ethyl 2-[4,5-bis (4-methoxyphenyl) thiazol-2-yl]pyrrol-1-ylacetate (KBT-3022), after Multiple Oral Administration in Mice
}

\author{
Yuichiro NaKAda, Masaaki FujiKawa, Norio Awata, Masayuki Kurotori* \\ Katsumasa ARAKAWA*, Kazumi ICHIGE**, Katsuyuki HoRI** \\ Pharmaceuticals Research Center, Kanebo, Ltd., Osaka; \\ *Research Laboratories, Torii \& Co., Ltd., Chiba; \\ **Tokai Research Laboratories, Daiichi Pure Chemicals Co., Ltd., Ibaraki
}

\section{Summary}

Absorption, distribution, excretion, enzyme induction and effect to platelet were investigated in male mice after oral administration of an antiplatelet drug, KBT-3022.

1. Radioactivity levels in the plasma $24 \mathrm{hr}$ after daily oral administration of ${ }^{14} \mathrm{C}-\mathrm{KBT}-3022$ reached a steady state by the 4 th dosing. The radioactivity levels after the 21st dosing showed a broad peak with about half of the $\mathrm{C}_{\max }$ after single dosing but had a similar $\mathrm{AUC}_{0-24 \mathrm{~h}}$.

2. Radioactivity levels in tissues $24 \mathrm{hr}$ after daily oral administration of ${ }^{14} \mathrm{C}-$ KBT-3022 increased with the number of doses and reached a steady state by the 21 st dosing except the spleen. The radioactivity levels in the lung, heart and testis after the 21st dosing were 5-6 times higher than those after single dosing, but those in the other tissues were lower than 4 times. Elimination of radioactivity from tissues after the 21st dosing was slower than that after single dosing. At 72 $\mathrm{hr}$ after the 21 st dosing, the radioactivity level in the aorta was $50 \%$ of the maximum and those in the skin, testis, lung, fat and spleen were $24-35 \%$ of the maximum. High level of radioactivity was noted in the deferent duct as revealed by whole body autoradiography.

3. No marked difference was observed in plasma concentration of 6-keto$\mathrm{PGF}_{1} \alpha$ and serum concentration of $\mathrm{TXB}_{2}$ between the single and repeated dosing groups, although the accumulation of radioactivity was noted in the aorta after

* 鳥居薬品株式会社 研究所 $\mathbf{T} 267$ 千葉県千葉市緑区大野台 1-2-1

** 第一化学薬品株式会社 東海研究所 $=319-11$ 茨城県那珂郡東海村村松 2117 
multiple doses of ${ }^{14} \mathrm{C}-\mathrm{KBT}-3022$. From these results, metabolites in the aorta would not inhibit the production of $\mathrm{PGI}_{2}$.

4. Excretion of radioactivity in the urine and feces did not change with the number of doses and was 1.3 and $92.7 \%$ of the cumulative dose, respectively, within $120 \mathrm{hr}$ after the 21 st dosing.

5. No significant effect on hepatic drug-metabolizing enzyme system was observed after repeated dosing of KBT-3022.

Key words : KBT-3022, Mouse, Repeated administration, Absorption, Distribution, Excretion, Enzyme induction

\section{緒言}

Ethyl 2-[4,5-bis (4-methoxyphenyl) thiazol-2yl]pyrrol-1-ylacetate (KBT-3022) は, シクロオ キシゲナーゼ阻害作用を有する新規抗血小板薬で ある11. 本剤のマウスにおける単回投与時の吸 収，分布および排泄については既に報告した ${ }^{2)}$.

今回， ${ }^{14} \mathrm{C}$ で標識した KBT-3022を用いて，雄 性マウスに反復経口投与し，その吸収，分布，排 泄および薬物代謝酵素系への影響について検討を 行った。 また血小板凝集と関連の深い thromboxane $\mathrm{A}_{2}\left(\mathrm{TX} \mathrm{A}_{2}\right)$ お よ び prostaglandin $\mathrm{I}_{2}$ $\left(\mathrm{PGI}_{2}\right)$ のそれぞれの安定代謝物 thromboxane
$\mathrm{B}_{2}\left(\mathrm{TXB}_{2}\right)$ おょひび 6-keto-prostaglandin $\mathrm{F}_{1} \alpha(6$ keto- $\left.\mathrm{PGF}_{1} \alpha\right)$ の血清または血嶈中濃度を測定 し， ${ }^{14} \mathrm{C}-\mathrm{KBT}-3022$ 経口投与後の血小板および動 脈中放射能濃度との関連性について検討した。

\section{実験材料および方法}

\section{1. 使用薬物}

${ }^{14} \mathrm{C}-\mathrm{KBT}-3022$ (Fig. 1) は第一化学薬品（株） 東海研究所で合成したものを使用した. 比放射能 は4.21 MBq/mg であり, 薄層クロマトグラフィ （TLC）により求めた放射化学的純度は $95 \%$ 以上 であった。

非標識の KBT-3022は鐘紡（株）薬品創薬研<smiles>COc1ccc(C(=O)C(O)c2ccc(OC)cc2)cc1</smiles><smiles>COc1ccc(-c2nc(-c3ccc[nH]3)sc2-c2ccc(OC)cc2)cc1</smiles><smiles>CCOC(=O)CCn1cccc1-c1nc(-c2ccc(OC)cc2)c(-c2ccc(OC)cc2)s1</smiles>

Fig. 1 Synthetic route of ${ }^{14} \mathrm{C}-\mathrm{KBT}-3022$ 
究所にて合成されたものを使用した.

\section{2. 実験動物}

実験動物として雄性 $\mathrm{ddY}$ 系 SPF マウス（生後 $5 \sim 8$ 週齢，体重約 $30 \mathrm{~g}$, 日本エスエルシー）を 用いた.

購入後のマウスは，水および固型飼料（MF， オリエンタル酵母工業または $\mathrm{CE}-2$, 日本クレア (株)）を自由に摂取させ, 温度 $23 \pm 2^{\circ} \mathrm{C}$, 湿度 $55 \pm 10 \%$ の条件下で 1 週間以上予備飼育をした のち試験に供した. 各試験に供する動物の例数は 全身オートラジオグラフィ， $\mathrm{TXB}_{2}, 6$-keto$\mathrm{PGF}_{1} \alpha$ の測定試験および酵素誘導試験を除き 1 群 3 匹とした．全身オートラジオグラフィは 1 群 1 匹，血清中 $\mathrm{TXB}_{2}$ の測定は 1 群 $3 \sim 8$ 匹，血 漿中 6-keto-PGF $1 \alpha$ の測定は 1 群 4 14匹，酵素 誘導試験は 4 匹の肝蔵を合したものを 1 例分と し, 1 群 4 例とした.

\section{3. 投与量および投与方法}

${ }^{14} \mathrm{C}-\mathrm{KBT}-3022$ に非標識 KBT-3022を加え，ク ロロホルムに溶解したのち, 窒素ガスでクロロホ ルムを除去した.これにポリエチレングリコール 400 : エタノール : 蒸留水 $(1: 1: 1)$ を加えて 溶解し， 0.2 または $2 \mathrm{mg} / 5 \mathrm{ml} / \mathrm{kg}$ で経ロゾンデ 針を用いて，マウスに 1 日 1 回最高21回経口投 与した. 投与放射能は約 $1.85 \mathrm{MBq} / \mathrm{kg}$ とした. また非標識 KBT-3022投与の場合は一定量を科 量し同様に投与液の調製，投与を行った。

\section{4. 試料の採取}

1）血液, 血漿中放射能濃度

${ }^{14} \mathrm{C}-\mathrm{KBT}-3022$ 雄性マウスに経口投与したの ち, 飼育ケージ ( $\mathrm{KN}-600$, 夏目製作所) に収め, 所定の時間にそれぞれエーテル麻酔下，腹大動脈 より採血致死させた. 得られた血液は遠心分離 （1800× $, 4^{\circ} \mathrm{C}, 15 \mathrm{~min} ）$ し，血漿を採取した。測 定時間は $1,4,7,10,14,17$ 回投与後 24 時間および 21 回投与後 $5,15,30$ 分， $1,2,4,6,8,12$ 時間打よ び24時間とした。
また，各測定時点においてへマトクリット値 (Ht) を測定し, 次式より血球移行率を算出し た.

血球移行率 $(\%)=\left(1-\frac{\mathrm{P}}{\mathrm{B}} \times \frac{100-\mathrm{Ht}}{100}\right) \times 100$

$\mathrm{P}$ : 血漿中放射能濃度 $(\mathrm{dpm} / \mathrm{m} l)$

B : 血液中放射能濃度 $(\mathrm{dpm} / \mathrm{m} l)$

$\mathrm{Ht}$ : ヘマトクリット值 $(\%)$

\section{2）全身オートラジオグラフィ}

${ }^{14} \mathrm{C}-\mathrm{KBT}-3022$ を雄性マウスに 21 回経口投与後 2, 24時間および72時間にそれぞれエーテル麻酔 死させ， $-70^{\circ} \mathrm{C}$ のドライアイス・アセトンによ り凍結した．得られた凍結屍体を $5 \%$ カルボキシ メチルセルロース (CMC) で包埋し, クライオ ミクロトーム（PMV450MP, LKB）を用いて約 $35 \mu \mathrm{m}$ の凍結切片を接着テープ (No. 810, 住友 スリーエム）に貼りつけて削り取った．得られた 凍結切片は $-25^{\circ} \mathrm{C}$ 前後で涷結乾燥し,切片表面を 保護膜 $(4 \mu \mathrm{m}$ ，ダイヤホイル）で被い，X線フ ィルム $\left(\mathrm{MARG}{ }^{3} \mathrm{H}\right.$ タイプ, コニカ) と密着させ, $4{ }^{\circ} \mathrm{C}$ で28日間露出して全身オートラジオグラムを 作製した。

\section{3）組織内放射能濃度}

${ }^{14} \mathrm{C}-\mathrm{KBT}-3022$ を雄性マウスに経口投与したの ち, 飼育ケージに収め, 所定の時間にそれぞれエ 一テル麻酔下, 腹大動脈より採血致死させ, 脳, 眼球, ハーダー腺, 顎下腺, 胸腺, 心臓, 肺, 肝 臓, 腎臓, 副腎, 脾蔵, 膵臓, 白色脂肪, 褐色脂 肪, 骨格筋, 皮膚, 骨䯣, 大動脈, 精巣, 前立 腺, 胃, 小腸, 大腸, 膀胼の各組織を摘出した.

血液および血漿はそれぞれ実験材料および方法 4.1)に準じて採取し, 血漿, 血液を除く各組織は それぞれの湿重量を測定し, 一部の組織について は小片を切り取り，その湿重量も測定して試料と した.

測定時間は 1 回投与後 24 時間, 7 回投与後 24 時間, 14 回投与後 24 時間および21回投与後 30 分, $2,8,24,72$ 時間とした.なお， 21 回投与後 72 時間 を除き, 実験材料および方法 4.1) と同一動物で 行った. 


\section{4）尿，粪中排泄率}

${ }^{14} \mathrm{C}-\mathrm{KBT}-3022$ 雄性マウスに経口投与したの ち, ガラス製代謝ケージ（第一化学薬品型, 石井 商店）に収め，自然排泄された尿および䔬を採取 した．測定時間は尿抢よび䔬とも毎回投与後 24 時間および21回投与後24時間毎に120時間なでと した.

21 回投与後 120 時間の尿および糞を採取後, マ ウスをエーテル麻酔死させ，屍体中の放射能測定 に供した。

\section{5. 血清中 $\mathrm{TXB}_{2}$ 濃度の測定}

経口投与後所定時間に腹大静脈より約 $400 \mu l$ 採血し， $37^{\circ} \mathrm{C} て ゙ 1$ 時間インキュベーションし， 遠心後血清を採取した，得られた血清を適宜希釈 し，ラジオイムノアッセイ (Thromboxane $\mathrm{B}_{2}\left[{ }^{3} \mathrm{H}\right]-\mathrm{RIA}$ キット，DU PONT NEN 社）で血 清中 $\mathrm{TXB}_{2}$ を測定した.

\section{6. 血漿中 6-keto-PGF $1 \alpha$ 濃度の測定}

経口投与後所定時間に, $10 \mu \mathrm{M}$ インドメタシ ンを含む $77 \mathrm{mM}$ EDTA 水溶液 $100 \mu \mathrm{l}$ の入ったシ リンジで, $900 \mu l$ の血液を腹大静脈より採血し た. 遠心後 (12000 rpm, 3 分)，得られた血漿を 2 匹分プールして合計 $1 \mathrm{~m} l$ として久米らの方法3) を参考に前処理操作を実施した. 前処理後, ラジ オイムノアッセイ（6-keto-PGF ${ }_{1} \alpha\left[{ }^{125} \mathrm{I}\right] \mathrm{RIA}$ キッ ト, Amersham) により 6-keto- $\mathrm{PGF}_{1} \alpha$ を定量し た。な抢，標品として用いた $\left[{ }^{3} \mathrm{H}\right]$-6-keto$\mathrm{PGF}_{1} \alpha(7.77 \mathrm{GBq} / \mu \mathrm{mol})$ は, DU PONT NEN 社 より入手した，逆相 TLC (HPTLC) による精製 段階でロスが生じるため, 回収率による補正を実 施した。分離精製の全過程における回收率は 44〜58\%であった.

\section{7. 酵素誘導試験}

\section{1) 投与方法}

雄性マウスに KBT-3022を $2 \mathrm{mg} / \mathrm{kg}$ で 1 日 1 回, 7 回反復経口投与した. また, 陰性対照（vehicle）として PEG-400:エタノール：蒸留水
（1:1:1）を $5 \mathrm{ml} / \mathrm{kg}$ で同様に反復経口投与し た。一方, 陽性対照群として phenobarbital sodium (和光純薬工業) を蒸留水に溶解し, $80 \mathrm{mg}$ / $5 \mathrm{ml} / \mathrm{kg}$ で 1 日 1 回, 7 回反復経口投与した.

2）蛋白質, $\mathbf{P}-450$ 含量および酵素活性の測定 KBT-3022あるいは vehicle および phenobarbital sodium を雄性マウスに投与したのち体重, 肝重量, 肝ミクロソーム蛋白量, チトクロム $\mathrm{P}-$ 450含量および酵素活性を測定した．すなわち, 最終投与後に絶食処置を施し 24 時間後にマウス を断頭放血死させたのち, 直ちに肝臓を摘出し, Matsubara らの方法4)に従ってミクロソームを調 製した。肝ミクロソーム蛋白量の測定は Lowry 法5)により測定した。チトクロム P-450含有量は 自記分光光度計 (UV-2100, 島津製作所) を用 いて Omura らの方法6)に準じて測定した。 Aminopyrine N-demethylase 活性は Matsubara らの方法7)に, aniline hydroxylase 活性は Imai らの方法8) に, p-nitroanisol O-demethylase 活性 はNetter らの方法 ${ }^{9)}$ に準じて測定した. UDPG transferase 活性は p-nitrophenol を基質として Isselbacher らの方法10)に準じてそれぞれ測定し た.

\section{8. 放射能の測定}

血漿，血液および各組織の一部あるいは全部に 組織溶解剂 SOLUENE-350(PACKARD) を加 えて溶解し, 必要に応じて過酸化ベンゾイル飽和 のベンゼン溶液を加え, 一夜振盪して脱色したの ちシンチレーターECONOFLUOR (Du Pont NEN Research Products) を加えて測定試料とし た. 尿は水を加えて希釈したのち，糞は70\%工 タノールを加えて粯拌均質化したのち，それぞれ シンチレーターATOMLIGHT (Du Pont NEN Research Products) を加えて測定試料とした。 屍体は $0.5 \mathrm{M}$ 水酸化ナトリウムおよびトルエンを 加えて72時間還流して溶解後，水を加えて攪拌 均質化し，シンチレーターATOMLIGHTを加 えて測定試料とした.

各試料中の放射能の測定は液体シンチレーショ 
ンカウンター（LSC-903, ALOKA）で 2 分間計 数することにより行った. なお, 計数効率の補正 は外部標準線源によるチャンネル比法によった.

\section{9. 試験成績の表示}

試験成績は平均值と標準誤差（S.E.）で表示し た. また, 放射能の検出限界はバックグランド値 (dpm) の 2 倍とした. 動物例数の半数以上が検 出限界以下の場合には N.D. (not detected) と表 示し, 3 例中 1 例が検出限界以下の場合には, 検 出限界以下を示したものもバックグラウンド值と の差の数値を用いて計算し， 3 例の平均値および 標準誤差 (S.E.) を算出した.さらに, 放射能濃 度はいずれも KBT-3022に換算して表示した。 有意差の検定には $t$ 検定を用いた.

\section{0. 速度論的パラメータの算出方法}

パラメータの算出はすべて 3 例の平均值を用 いて求めた. 半減期 $\left(\mathrm{t}_{1 / 2}\right)$ は実測值を用いて, 最小二乗法により求めたみかけの $\mathrm{t}_{1 / 2}$ として表示 した. 血液, 血漿中放射能濃度一時間曲線下面積 $\left(\mathrm{AUC}_{\mathrm{b}}, \mathrm{AUC}_{\mathrm{p}}\right)$ は台形法により算出し, 最終測 定時点以後における AUC の算出は消失相を直線
回帰して外挿することにより求めた.

\section{実 験 結 果}

\section{1. 反復投与試験}

非絶食雄性マウスに ${ }^{14} \mathrm{C}-\mathrm{KBT}-3022$ を $2 \mathrm{mg} /$ $\mathrm{kg}$ で 1 日 1 回, 最高21回経口投与した際の体内 動態について検討した.

\section{1）血液，血漿中放射能濃度}

毎回投与後 24 時間における血液および血漿中 放射能濃度を Fig. 2 に，21回投与後の血液およ び血漿中放射能濃度を Fig. 3 に示した。

毎回投与後 24 時間における血液および血漿中 放射能濃度はそれぞれ 4 回から 21 回投与まで 26 42 ng/ml, 28 $65 \mathrm{ng} / \mathrm{ml}$ を示し, 4 回投与 以後, 投与回数に伴う上昇傾向は認められなかっ た.

21 回投与後の血液中放射能濃度は投与後 2 時 間に最高濃度 $319 \mathrm{ng} / \mathrm{m} l$ を示したのち，4 時間か ら24時間まで $\mathrm{t}_{1 / 2} 5.8$ 時間で消失した。投与後 24 時間までの $\mathrm{AUC}_{\mathrm{b}}$ は $3.44 \mu \mathrm{g} \cdot \mathrm{h} / \mathrm{m} l$ であった，血 漿中放射能濃度は投与後 2 時間に最高濃度 496 $\mathrm{ng} / \mathrm{m} l$ を示したのち, 4 時間から 24 時間まで $\mathrm{t}_{1 / 2}$ 4.9 時間で消失した. 投与後 24 時間までの $\mathrm{AUC}_{\mathrm{p}}$

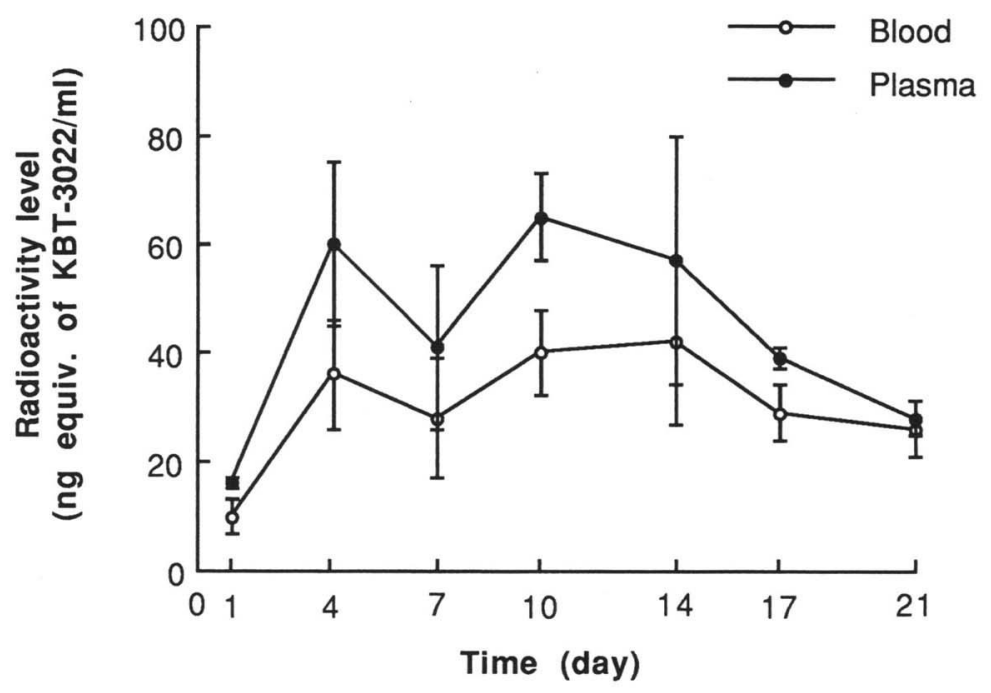

Fig. 2 Radioactivity levels in blood and plasma $24 \mathrm{hr}$ after daily oral administration of ${ }^{14} \mathrm{C}-\mathrm{KBT}-3022$ to non-fasting male mice (dose: $2 \mathrm{mg} /$ $\mathrm{kg} /$ day) Data are expressed as the mean values \pm S.E. of three animals. 


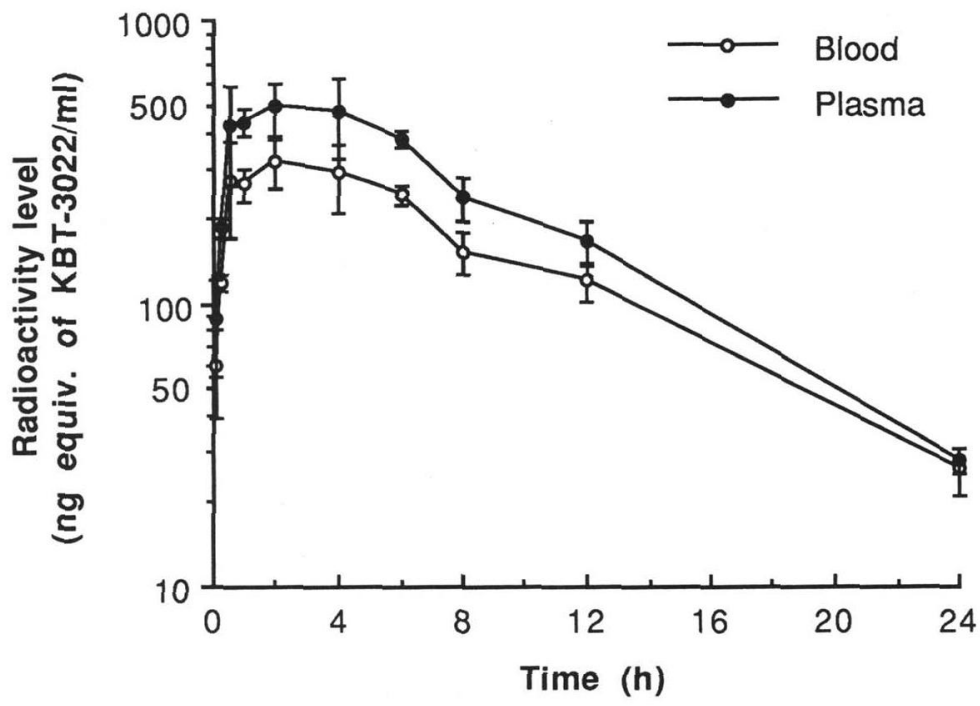

Fig. 3 Radioactivity levels in blood and plasma after a 21 day period of daily oral administration of ${ }^{14} \mathrm{C}-\mathrm{KBT}-3022$ to non-fasting male mice (dose: $2 \mathrm{mg} / \mathrm{kg} /$ day)

Data are expressed as the mean values \pm S.E. of three animals.

は $5.20 \mu \mathrm{g} \cdot \mathrm{h} / \mathrm{m} l$ であった.

また，血球への移行率は21回投与後 5 分から 24時間まで6.1〜34.2\%であった。

\section{2）全身オートラジオグラム（WARG）}

21回投与した際の WARG を Fig. 4 に示した.

21 回投与後 2 時間では胃内容物, 腸内容物, 胆汁，精管に高い放射能が認められ，次いで肝蔵 が高かった。腎臓，大動脈，包皮腺，副腎にも血 液より高い放射能が認められた。心臓, 肺, 精巣 上体, 八ーダ一腺, 褐色脂肪, 脾臓, 骨髄, 皮 膚, 舌, 顎下腺, 下垂体は血液とほほ同程度の放 射能であった。骨格筋, 膵臓, 胸腺, 精巣は血液 より低い放射能であった. 白色脂肪, 脳, 眼球の 放射能は最も低かった。

21 回投与後 24 時間では全体の放射能は低下し たが，2 時間と同様の分布パターンを示した.

21 回投与後 72 時間では全体の放射能はさらに 低下したが, 精管には高い放射能が認められ, 次 いで大動脈, 肝臓, 腸内容物に高かった. 肺, 副 腎, 皮虐, 精栄上体, 腎臓, 心臓には血液より高 い放射能が認められた．血液を含む他の組織にも 痕跡程度の低い放射能が認められた。

\section{3）組織内放射能濃度}

反復投与期間中の組織内放射能濃度を Table 1 に，21回投与後の組織内放射能濃度を Table 2 に示した.

各回投与後 24 時間における組織内放射能濃度 は大部分の組織が投与回数に伴い上昇し, 脾蔵は 21回投与以後も上昇する傾向が認められたが, 他の組織は21回投与むでに定常状態に達する傾 向が認められた. KBT-3022の作用部位である血 小板の毎回投与後 24 時間に打ける放射能濃度は, 検出限界以下であった。 大動脈は肝臓とほぼ同程 度の高い放射能濃度を示した。濃度上昇の大きな 組織は肺, 心臓および精巣であり, 21 回投与後 では単回投与後の 5〜6 倍を示した. 他の組織は 4 倍以下であった。

21 回投与後の組織内放射能濃度は, 胃および 小腸では最初の測定時点である投与後 30 分に, 眼球, 肺, 白色脂肪, 前立腺, 大腸および膀胱で は投与 8 時間に最高濃度を示した。他の組織は いずれも投与後 2 時間に最高濃度を示した. 21 回投与後30分では胃に最も高く，血漿中放射能 濃度 $422 \mathrm{ng} / \mathrm{ml}$ の 12 倍を示した。次いで肝蔵お 

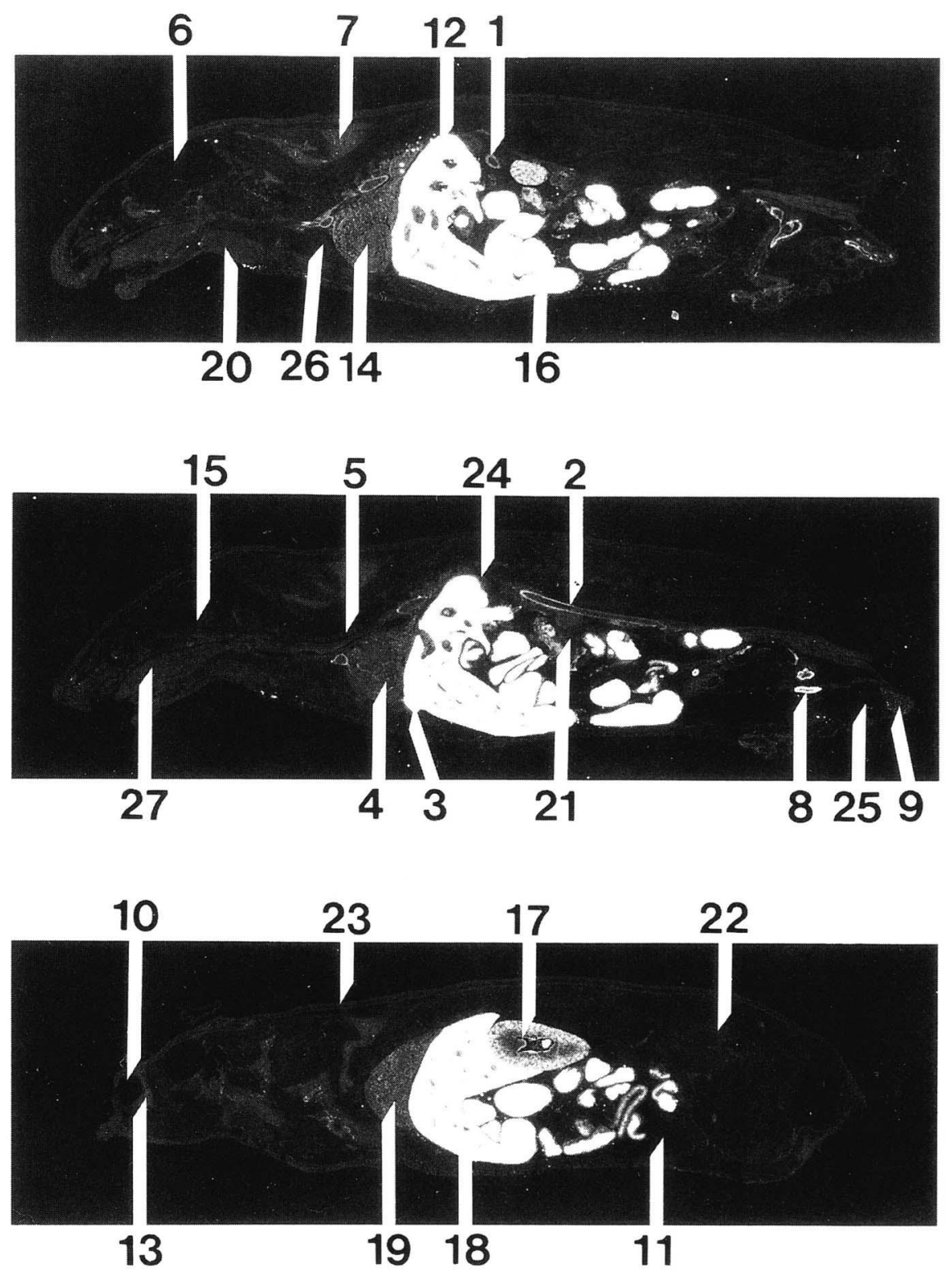

Fig. 4-1 


\section{$24 \mathrm{hr}$}
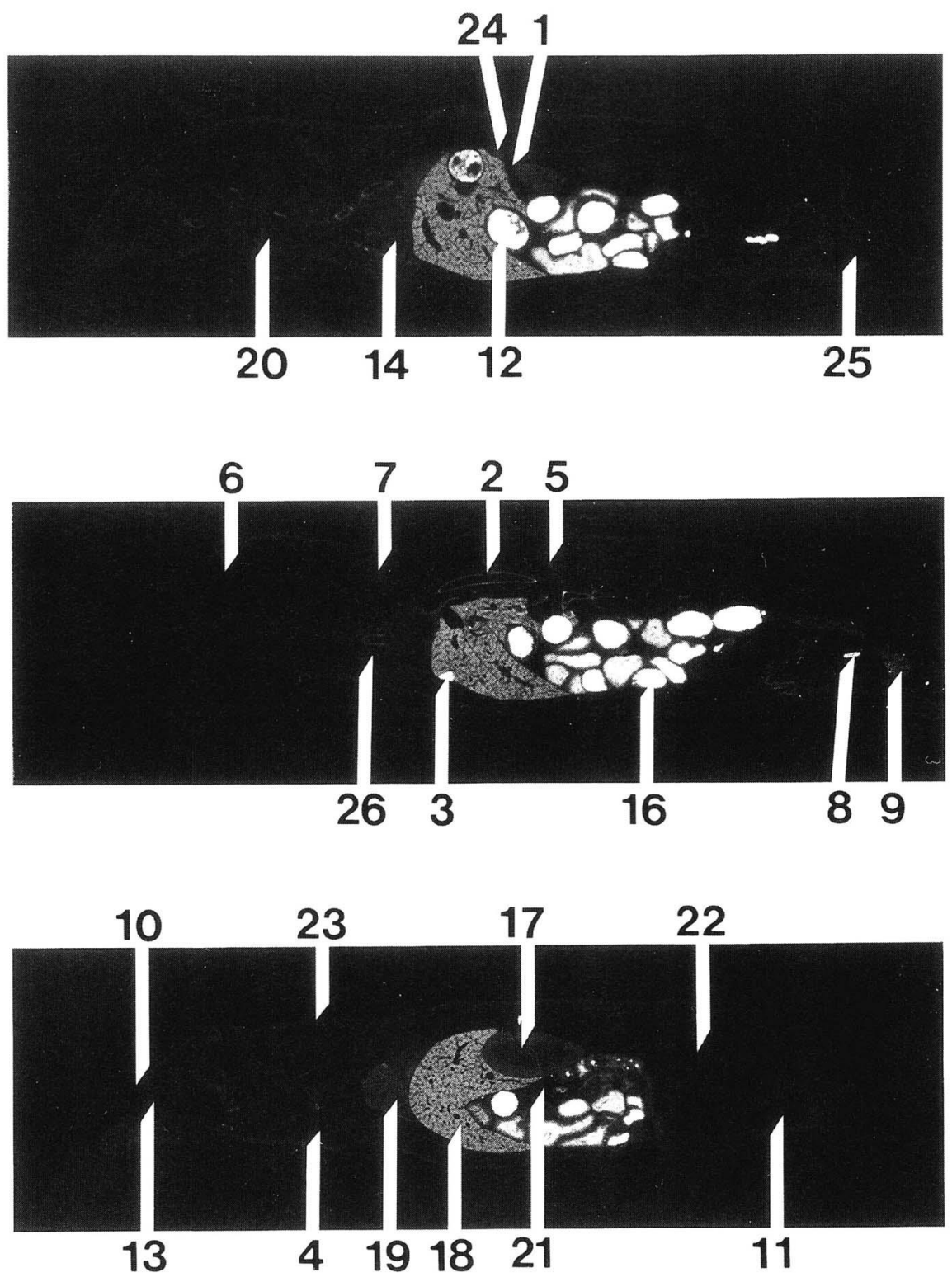

Fig. 4-2 


\section{$72 \mathrm{hr}$}
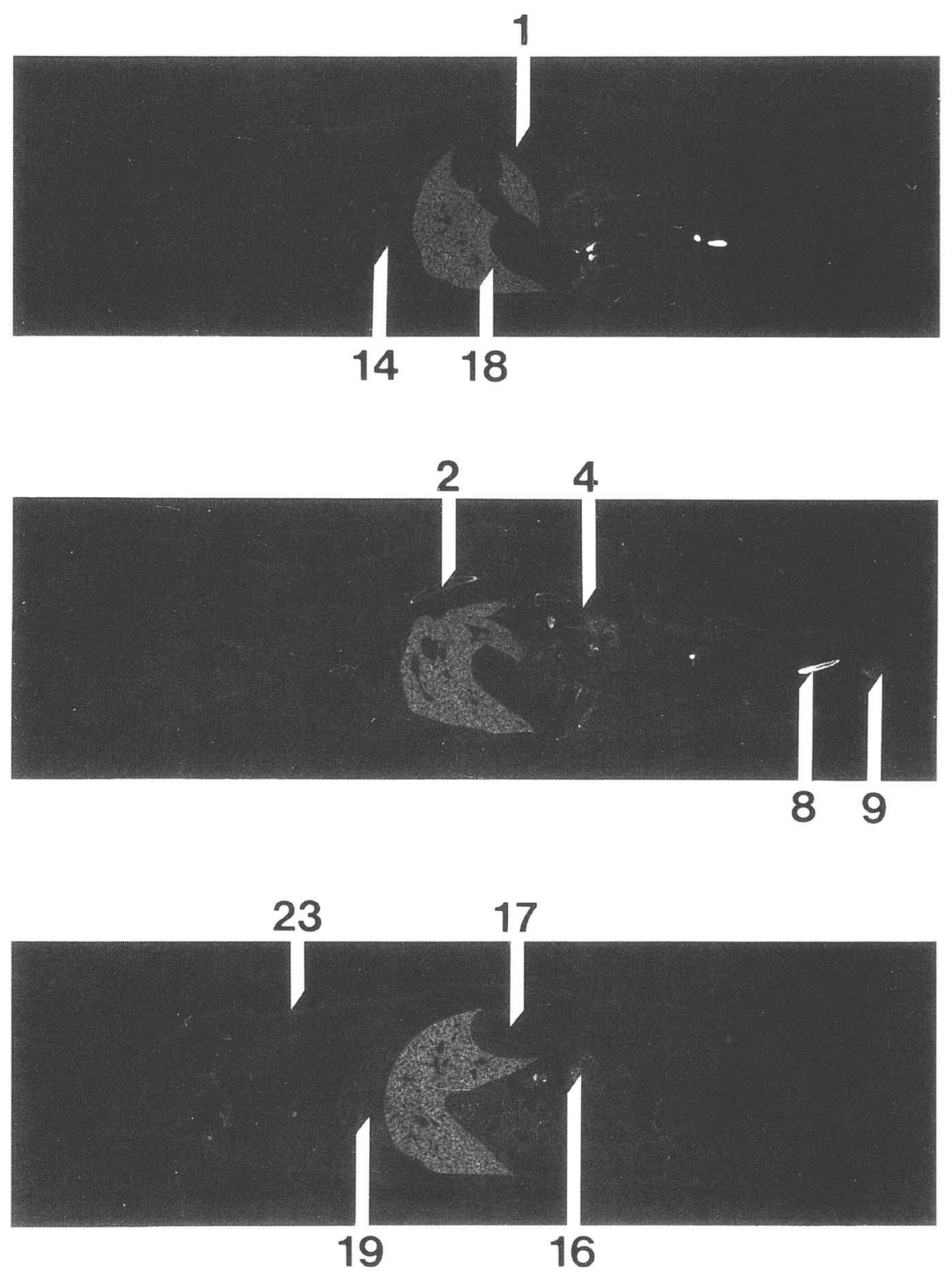

Fig. 4-3 Whole body autoradiograms after a 21 day period of daily oral administration of ${ }^{14} \mathrm{C}-\mathrm{KBT}-3022$ to nonfasting male mice (dose: $2 \mathrm{mg} / \mathrm{kg} /$ day)
1. Adrenal gland
2. Aorta
3. Bile in gall bladder
4. Blood
5. Bone marrow
6. Brain
7. Brown fat
8. Deferent duct
9. Epididymis
10. Eyeball
11. Fat
12. Gastric contents
13. Harderian gland
14. Heart
15. Hypophysis
16. Intestinal contents
17. Kidney
18. Liver
19. Lung
20. Mandibular gland
21. Pancreas
22. Skeletal muscle
23. Skin
24. Spleen
25. Testis
26. Thymus
27. Tongue 
Table 1 Radioactivity levels in tissue $24 \mathrm{hr}$ after daily oral administration of ${ }^{14} \mathrm{C}-\mathrm{KBT}-3022$ to non-fasting male mice (dose: $2 \mathrm{mg} / \mathrm{kg} /$ day)

\begin{tabular}{lcccc}
\hline \multirow{1}{1}{ Tissue } & \multicolumn{3}{c}{ Radioactivity level (ng equiv. of KBT-3022/g or ml) } \\
\cline { 2 - 5 } Plasma & Single dose & 7 doses & 14 doses & 21 doses \\
Blood & $16 \pm 1$ & $41 \pm 15$ & $57 \pm 23$ & $28 \pm 3^{*}$ \\
Platelet & $10 \pm 3$ & $28 \pm 11$ & $42 \pm 15$ & $26 \pm 5$ \\
Brain & N.D. & N.D. & N.D. & N.D. \\
Eyeball & N.D. & $5 \pm 1$ & $8 \pm 1$ & $8 \pm 2$ \\
Harderian gland & N.D. & N.D. & $12 \pm 3$ & $15 \pm 2$ \\
Mandibular gland & $18 \pm 3$ & $33 \pm 14$ & $50 \pm 5^{*}$ & $33 \pm 2^{*}$ \\
Thymus & $7 \pm 1$ & $20 \pm 6$ & $26 \pm 4^{*}$ & $26 \pm 3^{*}$ \\
Heart & $14 \pm 3$ & $26 \pm 7$ & $27 \pm 6$ & $30 \pm 6$ \\
Lung & $12 \pm 1$ & $36 \pm 9$ & $59 \pm 7^{*}$ & $63 \pm 12^{*}$ \\
Liver & $32 \pm 5$ & $135 \pm 14^{*}$ & $187 \pm 19^{*}$ & $199 \pm 24^{*}$ \\
Kidney & $155 \pm 22$ & $551 \pm 177$ & $588 \pm 26^{*}$ & $600 \pm 73^{*}$ \\
Adrenal gland & $39 \pm 5$ & $110 \pm 37$ & $116 \pm 16^{*}$ & $113 \pm 11^{*}$ \\
Spleen & N.D. & N.D. & N.D. & $90 \pm 5$ \\
Pancreas & $33 \pm 3$ & $68 \pm 16$ & $96 \pm 19^{*}$ & $113 \pm 23^{*}$ \\
Fat & $7 \pm 2$ & $15 \pm 7$ & $28 \pm 8$ & $22 \pm 4^{*}$ \\
Brown fat & $20 \pm 1$ & $39 \pm 4^{*}$ & $69 \pm 15^{*}$ & $72 \pm 6^{*}$ \\
Skeletal muscle & $17 \pm 1$ & $45 \pm 10^{*}$ & $63 \pm 13^{*}$ & $64 \pm 9^{*}$ \\
Skin & N.D. & $9 \pm 1$ & $11 \pm 1$ & $12 \pm 1$ \\
Bone marrow & $14 \pm 3$ & $29 \pm 5$ & $60 \pm 9^{*}$ & $56 \pm 7^{*}$ \\
Aorta & N.D. & N.D. & N.D. & N.D. \\
Testis & N.D. & $159 \pm 52$ & $517 \pm 128$ & $458 \pm 50$ \\
Prostate gland & $4 \pm 1$ & $12 \pm 3$ & $18 \pm 2^{*}$ & $20 \pm 1^{*}$ \\
Stomach & N.D. & N.D. & N.D. & N.D. \\
Small intestine & $14 \pm 47$ & $138 \pm 54$ & $195 \pm 77$ & $233 \pm 77$ \\
Large intestine & $89 \pm 10$ & $150 \pm 37$ & $111 \pm 20$ & $143 \pm 39$ \\
Urinary bladder & $109 \pm 34$ & $126 \pm 42$ & $90 \pm 10$ & $137 \pm 23$ \\
\hline & $41 \pm 10$ & $58 \pm 20$ & $64 \pm 2$ & $70 \pm 13$ \\
\hline
\end{tabular}

Data are expressed as the mean values \pm S.E. of three animals.

*: Significant difference from values of a single dose. $p<0.05$

N.D.: Not detected.

よび小腸に高く，それぞれ血墏中放射能濃度の 6 倍および 3 倍を示した. 大動脈，腎蔵，副腎お よび肺は血漿とほぼ同濃度でめった。血液，心 蔵, 脾臓, ハーダー腺, 大腸, 褐色脂肪および膀 胱は血漿中放射能濃度の $40 \sim 64 \%$, 顎下腺，膵 臓, 皮膚, 胸腺, 前立腺および白色脂肪は血漿中 放射能濃度の14〜30\%であった，骨䯣は検出限 界以下であった。他の組織は血漿中放射能濃度の 11\%以下であった.

21 回投与後 2 時間では胃および肝臓に高く,
それぞれ血漿中放射能濃度 $496 \mathrm{ng} / \mathrm{m} l$ の 9 倍お よび 7 倍を示した。次いで大動脈, 腎臓および 小腸に高く，ともに血漿中放射能濃度の 2 倍を 示した. 副腎, 肺, 褐色脂肪, ハーダー腺および 心臓は血漿とほほ同濃度であった。他の組織はい ずれも血漿中放射能濃度より低かった．

21 回投与後 8 時間では胃および肝蔵に高く, それぞれ血漿中放射能濃度 $236 \mathrm{ng} / \mathrm{ml}$ の 14 倍お よび10倍を示し, その他の組織も 2 時間とほぼ 同様の分布傾向を示した. 
Table 2 Radioactivity levels in tissue after a 21 day period of daily oral administration of ${ }^{14} \mathrm{C}-\mathrm{KBT}-3022$ to non-fasting male mice (dose: $2 \mathrm{mg} / \mathrm{kg} /$ day)

\begin{tabular}{|c|c|c|c|c|c|}
\hline \multirow[b]{2}{*}{ Tissue } & \multicolumn{5}{|c|}{ Radioactivity level (ng equiv. of KBT-3022/g or $\mathrm{m} l$ ) } \\
\hline & $30 \mathrm{~min}$ & $2 \mathrm{~h}$ & $8 \mathrm{~h}$ & $24 \mathrm{~h}$ & $72 \mathrm{~h}$ \\
\hline Plasma & $422 \pm 162$ & $496 \pm 104$ & $236 \pm 44$ & $28 \pm 3$ & $9 \pm 1$ \\
\hline Blood & $270 \pm 102$ & $319 \pm 65$ & $153 \pm 25$ & $26 \pm 5$ & $10 \pm 3$ \\
\hline Brain & $25 \pm 7$ & $38 \pm 10$ & $26 \pm 3$ & $8 \pm 2$ & $6 \pm 0$ \\
\hline Eyeball & $24 \pm 5$ & $34 \pm 4$ & $41 \pm 3$ & $15 \pm 2$ & N.D. \\
\hline Harderian gland & $233 \pm 107$ & $369 \pm 130$ & $269 \pm 45$ & $33 \pm 2$ & $21 \pm 2$ \\
\hline Mandibular gland & $126 \pm 43$ & $197 \pm 52$ & $110 \pm 16$ & $26 \pm 3$ & $20 \pm 2$ \\
\hline Thymus & $65 \pm 22$ & $129 \pm 45$ & $116 \pm 22$ & $30 \pm 6$ & $23 \pm 2$ \\
\hline Heart & $249 \pm 90$ & $363 \pm 90$ & $196 \pm 25$ & $63 \pm 12$ & $56 \pm 2$ \\
\hline Lung & $434 \pm 107$ & $534 \pm 70$ & $594 \pm 125$ & $199 \pm 24$ & $176 \pm 11$ \\
\hline Liver & $2633 \pm 847$ & $3526 \pm 645$ & $2439 \pm 245$ & $600 \pm 73$ & $476 \pm 26$ \\
\hline Kidney & $565 \pm 196$ & $938 \pm 217$ & $608 \pm 110$ & $113 \pm 11$ & $50 \pm 1$ \\
\hline Adrenal gland & $480 \pm 206$ & $543 \pm 94$ & $348 \pm 17$ & $90 \pm 5$ & N.D. \\
\hline Spleen & $234 \pm 59$ & $269 \pm 44$ & $236 \pm 26$ & $113 \pm 23$ & $65 \pm 3$ \\
\hline Pancreas & $126 \pm 49$ & $180 \pm 38$ & $109 \pm 16$ & $22 \pm 4$ & $15 \pm 2$ \\
\hline Fat & $59 \pm 10$ & $113 \pm 1$ & $149 \pm 14$ & $72 \pm 6$ & $28 \pm 3$ \\
\hline Brown fat & $199 \pm 78$ & $375 \pm 96$ & $266 \pm 34$ & $64 \pm 9$ & $37 \pm 4$ \\
\hline Skeletal muscle & $46 \pm 18$ & $64 \pm 17$ & $50 \pm 4$ & $12 \pm 1$ & $10 \pm 1$ \\
\hline Skin & $75 \pm 13$ & $139 \pm 22$ & $133 \pm 18$ & $56 \pm 7$ & $48 \pm 1$ \\
\hline Bone marrow & N.D. & $245 \pm 70$ & N.D. & N.D. & N.D. \\
\hline Aorta & $594 \pm 76$ & $939 \pm 80$ & $501 \pm 131$ & $458 \pm 50$ & $472 \pm 60$ \\
\hline Testis & $32 \pm 8$ & $63 \pm 11$ & $62 \pm 4$ & $20 \pm 1$ & $20 \pm 1$ \\
\hline Prostate gland & $62 \pm 28$ & $115 \pm 23$ & $184 \pm 94$ & N.D. & N.D. \\
\hline Stomach & $5047 \pm 372$ & $4240 \pm 1557$ & $3206 \pm 1201$ & $233 \pm 77$ & $50 \pm 4$ \\
\hline Small intestine & $1220 \pm 623$ & $919 \pm 266$ & $352 \pm 43$ & $143 \pm 39$ & $96 \pm 21$ \\
\hline Large intestine & $225 \pm 50$ & $270 \pm 63$ & $641 \pm 90$ & $137 \pm 23$ & $44 \pm 5$ \\
\hline Urinary bladder & $170 \pm 74$ & $202 \pm 38$ & $246 \pm 55$ & $70 \pm 13$ & $27 \pm 4$ \\
\hline
\end{tabular}

Data are expressed as the mean values \pm S.E. of three animals.

N.D.: Not detected.

21回投与後24時間では大動脈, 白色脂肪, 脾 臓および皮膚は最高濃度の $40 \sim 49 \%$ に, 眼球, 肺, 精巣, 膀胱, 胸腺, 脳抢よび大腸は21〜 $37 \%$ に減少した。その他の組織は最高濃度の 19\%以下に減少した.

21 回投与後72時間では大動脈は最高濃度の $50 \%$, 皮膚, 精巣および肺は30～35\%に減少し た.その他の組織は最高濃度の $24 \%$ 以下に減少 した.

\section{4）尿，䔬中への排泄}

毎回投与後 24 時間および 21 回投与後の尿およ
び糞中への累積投与量に対する排泄率を Table 3 に示した.

毎回投与後24時間における尿および䔬中への 累積投与量に対する排泄率は投与回数に伴う変化 は認められず，尿中に $1.0 \sim 1.3 \%$ が，翼中に 89.8〜96.7\%が排泄された.

21 回投与後 120 時間までの尿中には累積投与量 の $1.3 \%$, 糞中には $92.7 \%$ が排泄され，尿，䔬中 総排泄率は $94.0 \%$ であった。 また，この時点の体 内には累積投与量の $0.2 \%$ が認められた. 
Table 3 Comulative excretion of radioactivity in urine and feces during and after a 21 day period of daily oral administration of ${ }^{14} \mathrm{C}-\mathrm{KBT}-3022$ to non-fasting male mice (dose: $2 \mathrm{mg} / \mathrm{kg} /$ day)

\begin{tabular}{|c|c|c|c|c|}
\hline \multirow{2}{*}{\multicolumn{2}{|c|}{ Dose number }} & \multicolumn{3}{|c|}{$\begin{array}{l}\text { Excretion of radioactivity } \\
\text { (\% of comulative dose) }\end{array}$} \\
\hline & & Urine & Feces & Total \\
\hline 1 & & $1.0 \pm 0.1$ & $91.1 \pm 0.5$ & $92.1 \pm 0.4$ \\
\hline 2 & & $1.1 \pm 0.1$ & $89.8 \pm 4.4$ & $90.9 \pm 4.5$ \\
\hline 3 & & $1.1 \pm 0.1$ & $96.7 \pm 1.5$ & $97.8 \pm 1.4$ \\
\hline 4 & & $1.0 \pm 0.0$ & $90.7 \pm 2.0$ & $91.8 \pm 2.0$ \\
\hline 5 & & $1.0 \pm 0.0$ & $92.7 \pm 0.8$ & $93.8 \pm 0.9$ \\
\hline 6 & & $1.1 \pm 0.0$ & $94.4 \pm 0.7$ & $95.5 \pm 0.7$ \\
\hline 7 & & $1.1 \pm 0.0$ & $95.6 \pm 1.0$ & $96.7 \pm 1.0$ \\
\hline 8 & & $1.1 \pm 0.0$ & $95.2 \pm 1.1$ & $96.4 \pm 1.1$ \\
\hline 9 & & $1.2 \pm 0.0$ & $94.8 \pm 1.1$ & $96.0 \pm 1.1$ \\
\hline 10 & & $1.2 \pm 0.0$ & $93.8 \pm 0.9$ & $95.0 \pm 0.9$ \\
\hline 11 & & $1.2 \pm 0.0$ & $92.8 \pm 0.9$ & $94.0 \pm 0.9$ \\
\hline 12 & & $1.2 \pm 0.0$ & $92.2 \pm 1.0$ & $93.5 \pm 0.9$ \\
\hline 13 & & $1.2 \pm 0.0$ & $92.6 \pm 0.9$ & $93.8 \pm 0.9$ \\
\hline 14 & & $1.3 \pm 0.0$ & $92.8 \pm 0.9$ & $94.1 \pm 0.9$ \\
\hline 15 & & $1.3 \pm 0.0$ & $93.0 \pm 0.7$ & $94.2 \pm 0.7$ \\
\hline 16 & & $1.3 \pm 0.0$ & $92.1 \pm 0.6$ & $93.4 \pm 0.6$ \\
\hline 17 & & $1.3 \pm 0.0$ & $92.4 \pm 0.7$ & $93.7 \pm 0.7$ \\
\hline 18 & & $1.3 \pm 0.0$ & $92.9 \pm 0.7$ & $94.1 \pm 0.7$ \\
\hline 19 & & $1.3 \pm 0.0$ & $92.4 \pm 0.7$ & $93.7 \pm 0.6$ \\
\hline 20 & & $1.3 \pm 0.0$ & $92.4 \pm 0.6$ & $93.7 \pm 0.6$ \\
\hline \multirow[t]{5}{*}{21} & $24^{*}$ & $1.3 \pm 0.1$ & $92.4 \pm 0.6$ & $93.7 \pm 0.6$ \\
\hline & $48^{*}$ & $1.3 \pm 0.1$ & $92.6 \pm 0.6$ & $93.9 \pm 0.6$ \\
\hline & $72^{*}$ & $1.3 \pm 0.1$ & $92.7 \pm 0.6$ & $94.0 \pm 0.6$ \\
\hline & $96^{*}$ & $1.3 \pm 0.1$ & $92.7 \pm 0.6$ & $94.0 \pm 0.6$ \\
\hline & $120^{*}$ & $1.3 \pm 0.1$ & $92.7 \pm 0.6$ & $94.0 \pm 0.6$ \\
\hline
\end{tabular}

Residual radioactivity in carcass at $120 \mathrm{hr}$ after the final dose: $0.2 \pm 0.0 \%$ of comulative dose

*: Hours after the final dose

All samples were collected for a $24 \mathrm{hr}$ period after daily dosing and then every $24 \mathrm{hr}$ after the final dose.

Data are expressed as the mean values \pm S.E. of three animals.

\section{2. 血清中 $\mathbf{T X B}_{2}$ 濃度，血墏中 6 -keto-PGF ${ }_{1} \alpha$ 濃度}

マウスに KBT-3022を単回経口投与した時の 血清中 $\mathrm{TXB}_{2}$ 濃度を Fig. 5 に，血墏中 6-keto$\mathrm{PGF}_{1} \alpha$ 濃度を Fig. 6 に示す.

$\mathrm{TXB}_{2}$ 濃度は $2 \mathrm{mg} / \mathrm{kg}$ 投与で, 投与後 $0.5,2$,
4, 8 時間， $0.2 \mathrm{mg} / \mathrm{kg}$ 投与で 0.5 時間にそれぞれ 有意な減少が認められた。 6-keto- $\mathrm{PGF}_{1} \alpha$ 濃度は, $2 \mathrm{mg} / \mathrm{kg}$ 投与で投与後 $2,4,8$ 時間に有意な減少 が認められたが, $0.2 \mathrm{mg} / \mathrm{kg}$ 投与時には有意な減 少が認められなかった。連続経口投与後 24 時間 目の血清中 $\mathrm{TXB}_{2}$ 濃度を Fig. 7 に，血漿中 6keto-PGF $1 \alpha$ 濃度を Fig. 8 に示す.

$\mathrm{TXB}_{2}$ 濃度は vehicle 投与群, KBT-3022投与 群ともほぼ同様の值を示し，連投による抑制傾向 は認められなかった。 また，6-keto-PGF $1 \alpha$ 濃度 も $0.2,2 \mathrm{mg} / \mathrm{kg}$ の連続投与で vehicle 投与群とほ ほ同様の值を示し，連投による抑制傾向は認めら れなかった。

\section{3. 酵素誘導試験}

非絶食雄性マウスに KBT-3022を $2 \mathrm{mg} / \mathrm{kg}$ で 1 日 1 回, 7 回経口投与した際の肝薬物代謝酵素 活性を Table 4 に示した。

\section{1）体重および肝重量}

KBT-3022投与群では, 体重, 肝重量および体 重に対する肝重量比において有意な変化は認めら れなかった. 一方, phenobarbital sodium 投与群 では, 肝重量に有意な変化は認められなかったも のの，体重に約10\%の減少が認められた $(p<0.01)$.また, 体重に対する肝重量比におい て約20\%の増加が認められた $(p<0.001)$.

\section{2）肝ミクロソーム蛋白量}

KBT-3022投与群では, 肝ミクロソーム蛋白量 に変化は認められなかった。一方, phenobarbital sodium 投与群では, 肝臓 $1 \mathrm{~g}$ 当たりおよび 肝蔵当たりの肝ミクロソーム蛋白量において増加 傾向が認められた。

\section{3）旰薬物代謝酵素活性}

KBT-3022投与群では, aminopyrine N-demethylase, aniline hydroxylase, p-nitroanisol Odemethylase および UDPG transferase の各酵素 活性に有意な変化は認められなかった。一方, phenobarbital sodium 投与群では, UDPG transferase 活性および p-nitroanisol O-demethylase 活性の肝ミクロソーム蛋白 $1 \mathrm{mg}$ 当たり抢よび肝 


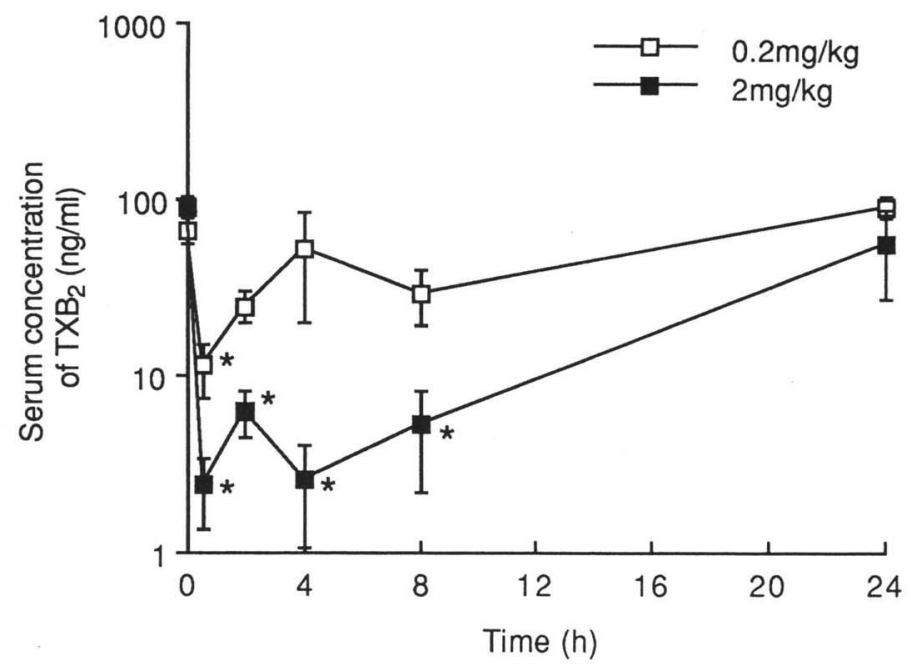

Fig. 5 Serum concentration of $\mathrm{TXB}_{2}$ after oral administration of KBT-3022 to fasting male mice (dose: $0.2 \mathrm{mg} / \mathrm{kg}, 2 \mathrm{mg} / \mathrm{kg}$ ) Each point represents the mean \pm S.E. $(n=3$ or 4$)$.

*; Significant difference from initial concentration by $t$ test $(p<0.05)$

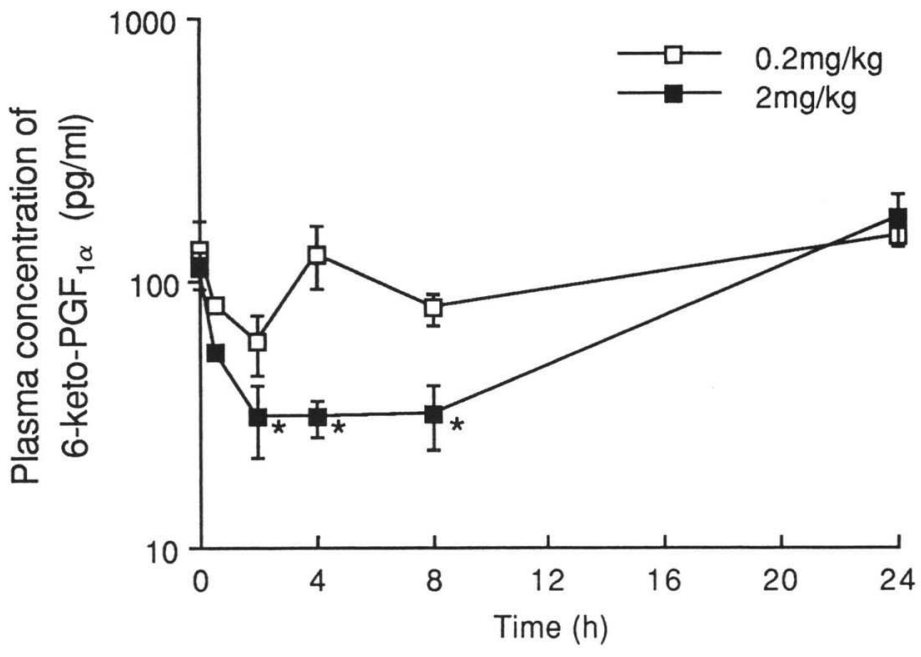

Fig. 6 Plasma concentration of 6-keto-PGF $\alpha$ after oral administration of KBT-3022 to fasting male mice (dose: $0.2 \mathrm{mg} / \mathrm{kg}, 2 \mathrm{mg} / \mathrm{kg}$ ) Each point represents the mean \pm S.E. $(n=2-4)$.

*; Significant difference from initial concentration by $t$ test $(p<0.05)$ 


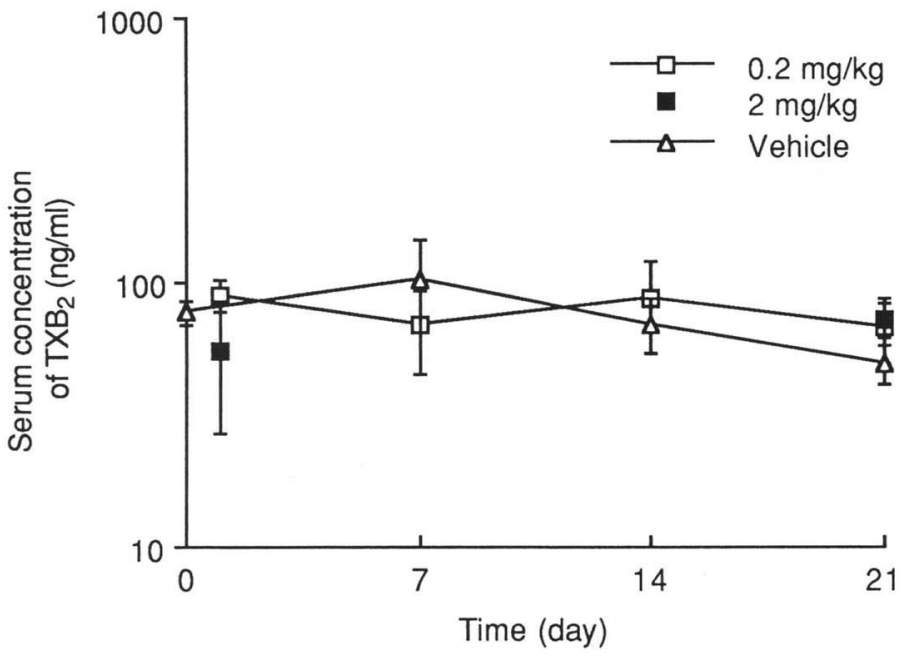

Fig. 7 Serum concentration of $\mathrm{TXB}_{2} 24 \mathrm{hr}$ after daily oral administration of KBT-3022 to mice (dose: $0.2 \mathrm{mg} / \mathrm{kg}, 2 \mathrm{mg} / \mathrm{kg}$, vehicle) Each point represents the mean \pm S.E. $(n=3-8)$.

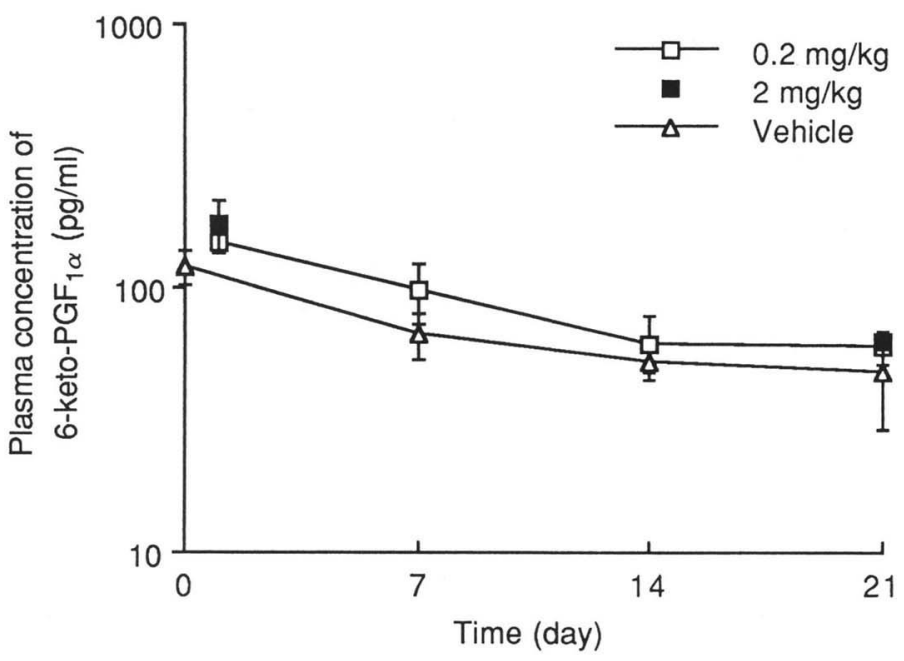

Fig. 8 Plasma concentration of 6-keto-PGF $\alpha 24 \mathrm{hr}$ after daily oral administration of KBT-3022 to mice (dose: $0.2 \mathrm{mg} / \mathrm{kg}, 2 \mathrm{mg} / \mathrm{kg}$, vehicle)

Each point represents the mean \pm S.E. $(n=2-7)$. 
Table 4 Effect of treatment with KBT-3022 or phenobarbital sodium for 7 days on hepatic drug-metabolizing enzymes of mice

\begin{tabular}{|c|c|c|c|c|c|c|}
\hline \multirow{2}{*}{$\begin{array}{l}\text { Parameter } \\
\text { Body weight }(\mathrm{g})\end{array}$} & \multicolumn{2}{|c|}{$\begin{array}{c}\text { Vehicle } \\
(5 \mathrm{ml} / \mathrm{kg} / \text { day })\end{array}$} & \multicolumn{2}{|c|}{$\begin{array}{c}\mathrm{KBT}-3022 \\
(2 \mathrm{mg} / \mathrm{kg} / \text { day })\end{array}$} & \multicolumn{2}{|c|}{$\begin{array}{c}\text { Phenobarbital sodium } \\
(80 \mathrm{mg} / \mathrm{kg} / \text { day })\end{array}$} \\
\hline & $36.8 \pm 0.6$ & $(1.00)$ & $35.6 \pm 0.5$ & $(0.97)$ & $33.7 \pm 0.3$ & $(0.92)^{*}$ \\
\hline Liver weight $(\mathrm{g})$ & $1.83 \pm 0.08$ & $(1.00)$ & $1.73 \pm 0.01$ & $(0.95)$ & $2.03 \pm 0.04$ & $(1.11)$ \\
\hline Liver weight/body weight (\%) & $4.97 \pm 0.13$ & $(1.00)$ & $4.86 \pm 0.06$ & $(0.98)$ & $6.02 \pm 0.09$ & $(1.21)^{\#}$ \\
\hline \multicolumn{7}{|l|}{ Microsomal protein content } \\
\hline$(\mathrm{mg} / \mathrm{g}$ liver $)$ & $38.60 \pm 0.48$ & $(1.00)$ & $39.39 \pm 1.34$ & $(1.02)$ & $43.74 \pm 5.04$ & $(1.13)$ \\
\hline (mg/liver) & $70.45 \pm 2.44$ & $(1.00)$ & $68.04 \pm 2.32$ & $(0.97)$ & $89.00 \pm 10.98$ & $(1.26)$ \\
\hline \multicolumn{7}{|l|}{ Aminopyrine $\mathrm{N}$-demethylase activity } \\
\hline$(\mathrm{nmol} / \mathrm{min} / \mathrm{mg}$ protein $)$ & $9.97 \pm 0.27$ & $(1.00)$ & $10.39 \pm 0.23$ & $(1.04)$ & $20.19 \pm 0.89$ & $(2.03)^{\#}$ \\
\hline$(\mathrm{nmol} / \mathrm{min} / \mathrm{g}$ liver $)$ & $385 \pm 8$ & $(1.00)$ & $409 \pm 14$ & $(1.06)$ & $870 \pm 65$ & $(2.26)^{\#}$ \\
\hline$(\mu \mathrm{mol} / \mathrm{min} /$ liver $)$ & $0.703 \pm 0.032$ & $(1.00)$ & $0.706 \pm 0.022$ & $(1.00)$ & $1.768 \pm 0.147$ & $(2.51)^{\#}$ \\
\hline \multicolumn{7}{|l|}{ Aniline hydroxylase activity } \\
\hline$(\mathrm{nmol} / \mathrm{min} / \mathrm{mg}$ protein $)$ & $0.717 \pm 0.046$ & $(1.00)$ & $0.697 \pm 0.015$ & $(0.97)$ & $1.044 \pm 0.080$ & $(1.46)^{\dagger}$ \\
\hline$(\mathrm{nmol} / \mathrm{min} / \mathrm{g}$ liver $)$ & $27.7 \pm 2.0$ & $(1.00)$ & $27.5 \pm 1.3$ & $(0.99)$ & $44.6 \pm 2.7$ & $(1.61)^{*}$ \\
\hline$(\mathrm{nmol} / \mathrm{min} /$ liver $)$ & $50.2 \pm 1.5$ & $(1.00)$ & $47.5 \pm 2.2$ & $(0.95)$ & $90.6 \pm 6.2$ & $(1.80)^{\#}$ \\
\hline \multicolumn{7}{|l|}{ P-Nitroanisol O-demethylase activity } \\
\hline$(\mathrm{nmol} / \mathrm{min} / \mathrm{mg}$ protein $)$ & $6.76 \pm 1.37$ & $(1.00)$ & $6.03 \pm 0.49$ & $(0.89)$ & $9.32 \pm 0.81$ & $(1.38)$ \\
\hline$(\mathrm{nmol} / \mathrm{min} / \mathrm{g}$ liver $)$ & $259 \pm 50$ & $(1.00)$ & $236 \pm 13$ & $(0.91)$ & $397 \pm 28$ & $(1.53)$ \\
\hline$(\mathrm{nmol} / \mathrm{min} /$ liver $)$ & $485 \pm 108$ & $(1.00)$ & $407 \pm 24$ & $(0.84)$ & $805 \pm 51$ & $(1.66)^{\dagger}$ \\
\hline \multicolumn{7}{|l|}{ UDPG transferase activity } \\
\hline$(\mathrm{nmol} / \mathrm{min} / \mathrm{mg}$ protein $)$ & $0.784 \pm 0.055$ & $(1.00)$ & $0.784 \pm 0.051$ & $(1.00)$ & $0.667 \pm 0.054$ & $(0.85)$ \\
\hline$(\mathrm{nmol} / \mathrm{min} / \mathrm{g}$ liver $)$ & $30.3 \pm 2.4$ & $(1.00)$ & $31.1 \pm 2.9$ & $(1.03)$ & $29.6 \pm 5.0$ & $(0.98)$ \\
\hline$(\mathrm{nmol} / \mathrm{min} /$ liver $)$ & $54.8 \pm 2.1$ & $(1.00)$ & $53.7 \pm 5.0$ & $(0.98)$ & $60.0 \pm 10.2$ & $(1.09)$ \\
\hline \multicolumn{7}{|l|}{ Cytochrome P-450 content } \\
\hline (nmol/mg protein) & $0.523 \pm 0.078$ & $(1.00)$ & $0.524 \pm 0.070$ & $(1.00)$ & $0.869 \pm 0.099$ & $(1.66)^{\dagger}$ \\
\hline (nmol/g liver) & $20.2 \pm 3.0$ & $(1.00)$ & $20.5 \pm 2.6$ & (1.01) & $39.1 \pm 7.3$ & $(1.94)$ \\
\hline (nmol/liver) & $36.5 \pm 4.7$ & $(1.00)$ & $35.4 \pm 4.5$ & $(0.97)$ & $79.3 \pm 14.9$ & $(2.17)^{\dagger}$ \\
\hline
\end{tabular}

Data are expressed as the mean values \pm S.E. of four animals.

Values in parentheses are expressed as the ratio of drug treatment to Vehicle.

Significant difference from value of vehicle: ${ }^{\dagger} ; p<0.05,{ }^{*} ; p<0.01, \# ; p<0.001$

臓 $1 \mathrm{~g}$ 当たりの活性に有意な変化は認められなか ったが，他の各酵素活性においては有意な増加が 認められた。

\section{4）チトクロム P-450含量}

KBT-3022投与群では, チトクロム P-450含量 に有意な変化は認められなかった。一方, phenobarbital sodium 投与群では, 肝蔵 $1 \mathrm{~g}$ 当た りの含量に有意な変化は認められなかったもの の, 肝ミクロソーム蛋白 $1 \mathrm{mg}$ 当たりおよび肝臓 当たりの含量が約70〜120\% 増加した $(p<0.05)$.

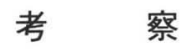

雄性マウスに ${ }^{14} \mathrm{C}-\mathrm{KBT}-3022$ を $2 \mathrm{mg} / \mathrm{kg}$ で21 回反復経口投与した際の体内動態について検討し た. Fig. 2 に示すように毎回投与後 24 時間におけ る血漿中放射能濃度は 4 回投与でほぼ定常状態 に達した. 21 回投与後の血漿中放射能濃度は Fig. 3 に示すように単回投与群 ${ }^{2)}$ と比較して $\mathrm{C}_{\max }$ が約 $1 / 2$ になり，ブロードなピークとなった．こ の原因として, 吸収速度が単回投与と比較し低下 したと考えられるが，詳細は不明である.なお， 24時間までの $\mathrm{AUC}_{\mathrm{p}}$ には顕著な差は認められな 
かったなた，血漿中からの消失半減期もほぼ同 様の值を示した。ほとんどの組織中濃度は Table 1 に示すように21回投与までにほぼ定常状 態に達する傾向を示したが, 脾臓は 21 回投与後 に単回投与群の 3 倍の放射能濃度を示し, さら に上昇する傾向が認められた。しかしながら、マ ウスに抢ける亜急性毒性試験の結果では2 500 $\mathrm{mg} / \mathrm{kg}$ の高投与量を投与した雄性マウスの脾蔵 にわずかな重量増加がみられた程度で, 病理組織 学的な変化も認められていない. KBT-3022の作 用部位である血小板では毎回投与後 24 時間にお ける放射能濃度は検出限界以下であった。 また，

肺, 心蔵および精巣の放射能濃度は21回投与後 で単回投与群の 5 6 倍, 他の組織は 4 倍以下で あり，血漿中濃度が約 2 倍になることを考慮す ると, 組織への蓄積は大きくないものと考えられ た.

21 回投与後の各組織からの消失は Table 2 に 示すように単回投与群に比較して遅く, 21 回投 与後72時間では大動脈に最高濃度の $50 \%$, 皮膚, 精巣扔よび肺に最高濃度の30 34\%の放射能濃 度が認められた。他の組織は最高濃度の $25 \%$ 以 下に減少した。 また，21回投与後72時間の全身 オートラジオグラムより, 精管にも高い放射能が 認められた. 単回投与に比べ連投後の各組織から の消失が遅くなる理由として, 単回投与に比べ連 投時の放射能濃度が相対的に高くなり，消失相で の3 相性が顕在化したのではないかと考えられ る.

${ }^{14} \mathrm{C}-\mathrm{KBT}-3022$ 単回経口投与の場合, 血小板中 放射能濃度は血漿中濃度の $2.4 \sim 15.7$ 倍であるの に対して，大動脈中放射能濃度は最大で約 $50 \%$ であった ${ }^{2)}$. Fig. 5 に示すように，KBT-3022の $0.2 \mathrm{mg} / \mathrm{kg}$ 単回経口投与時の血清中 $\mathrm{TXB}_{2}$ 濃度 は投与前值に比べ有意な減少が認められた。しか ᄂ, Fig. 6 に示すように血漿中 6-keto- $\mathrm{PGF}_{1} \alpha$ 濃 度は $0.2 \mathrm{mg} / \mathrm{kg}$ 投与で有意な減少が認められず, 血小板, 大動脈中放射能濃度をほぼ反映した結果 が得られた。

マウスに ${ }^{14} \mathrm{C}-\mathrm{KBT}-3022$ を連投すると，他の
臟器に比べ大動脈に高い放射能濃度が認められた。 KBT-3022は血小板中のシクロオキシゲナーゼを 阻害することにより，血小板凝集抑制作用を示す $\mathrm{TXA}_{2}$ の生成を抑制するが，シクロオキシゲナー ゼは血管内皮細胞にも存在し， $\mathrm{TXA}_{2}$ とは逆に血 小板凝集抑制作用を有する prostaglangin $\mathrm{I}_{2}\left(\mathrm{PGI}_{2}\right)$ の産生に深く関わっている11). 血小板 凝集抑制作用を有する $\mathrm{PGI}_{2}$ の生成を抑制するこ とは，血小板の凝集を促すことになる．よって ${ }^{14} \mathrm{C}-\mathrm{KBT}-3022$ の連投で大動脈中に高い放射能濃 度が認められることは，薬効の面から問題となる と考えられた。そこで $\mathrm{PGI}_{2}$ の安定代謝物 6keto-PGF $1 \alpha$ の血墏中濃度を測定することによ り，大動脈中シクロオキシゲナーゼ活性への影響 を検討した。 また，同時に TXA 2 の安定代謝物 である $\mathrm{TXB}_{2}$ の血清中濃度を測定し，作用部位 である血小板中シクロオキシゲナーゼ活性への影 響についても検討した. ${ }^{14} \mathrm{C}-\mathrm{KBT}-3022$ を $2 \mathrm{mg} /$ $\mathrm{kg}$ 単回経口投与後 8 時間目の大動脈中放射能濃 度は123 ng/g であり 2), 6-keto- $\mathrm{PGF}_{1} \alpha$ 濃度は有意 な減少を示す。しかし，KBT-3022 $2 \mathrm{mg} / \mathrm{kg} 21$ 回連投 24 時間後の大動脈中放射能濃度は, Table 2 に示すように $458 \mathrm{ng} / \mathrm{g}$ であるが，Fig. 8 に示 すように 6-keto- $\mathrm{PGF}_{1} \alpha$ 濃度はコントロール群と 比較し, 有意な減少を示さなかった。すなわち ${ }^{14} \mathrm{C}-\mathrm{KBT}-3022$ の連投により大動脈中に高い放射 能濃度は認められるが，直接 $\mathrm{PGI}_{2}$ 産生に影響を 及ぼさないことを示している，言い換えれば，大 動脈中に検出される放射能は $\mathrm{PGI}_{2}$ 生成に対して 阻害活性のない代謝物として存在していることを 示唆している.なお大動脈中代謝物の存在形態は 放射能の絶対量が少なすぎるため明らかにするこ とは不可能であった．たたし，単回投与時の血漿 中放射能のほとんどはエチルエステルのエチルが 脱離した代謝物であることを確認している12). また，毎投与 24 時間後の $\mathrm{TXB}_{2}$ 濃度は初回投与 後 24 時間後の $\mathrm{TXB}_{2}$ 濃度と変化なく, 連投によ って薬効である血小板中シクロオキシゲナーゼ活 性が増強されることもないことがわかった．

尿, 糞中への排泄は Table 3 に示すように反復 
投与期間中, 投与回数に伴う変化は認められず, $2 \mathrm{mg} / \mathrm{kg}$ の反復投与は排泄経路に変化を及ほささ ないものと考えられた.

さらに，雄性マウスに KBT-3022を $2 \mathrm{mg} / \mathrm{kg}$ で 7 日反復経口投与し, 肝薬物代謝酵素系に対 する影響を調べたところ, Table 4 に示すように 測定した代謝酵素活性については vehicle 群と差 が認められなかったことより, 本薬物の肝薬物代 謝酵素活性への影響は小さいものと考えられた.

\section{要 約}

1）非絶食雄性マウスに $2 \mathrm{mg} / \mathrm{kg}$ 反復経口投 与した際, 毎回投与後 24 時間における血漿中放 射能濃度は 4 回投与でほぼ定常状態に達した。 21 回投与後の血漿中放射能濃度は単回投与群と 比較して $\mathrm{C}_{\max }$ が約 $1 / 2$ になり，ブロードなピー クとなったが，24時間なでの $\mathrm{AUC}_{\mathrm{p}}$ には顕著な 差は認められなかった。

2）非絶食雄性マウスに $2 \mathrm{mg} / \mathrm{kg}$ 反復経口投 与した際, 各回投与後 24 時間の組織内放射能濃 度は脾蔵が 21 回投与後も上昇する傾向が認めら れたものの，他の組織は21回投与までに定常状 態に達する傾向が認められた．肺，心臓および精 巣は 21 回投与で単回投与の $5 〜 6$ 倍を示したが， 他の組織は 4 倍以下であった. 21 回投与後の各 組織からの消失は単回投与と比較して遅く, 21 回投与後 72 時間では大動脈に最高濃度の $50 \%$ が， 皮膚, 精巣, 肺, 白色脂肪拈よび脾臓に 24 $35 \%$ が認められた。 また，全身オートラジオグ ラムにおいて精管に高い放射能が認められた。

3） ${ }^{14} \mathrm{C}-\mathrm{KBT}-3022$ 連投による大動脈への放射 能蓄積の影響を 6-keto-PGF $1 \alpha$ の血漿濃度を測定 することにより検討した，また，同時に $\mathrm{TXB}_{2}$ の血清中濃度を測定し，作用部位である血小板へ の影響についても検討した。 その結果, ${ }^{14} \mathrm{C}-$ KBT-3022の連投により大動脈中に高い放射能濃 度が認められるが，直接 $\mathrm{PGI}_{2}$ 産生に影響を及ほ さず，大動脈中の放射性物質は $\mathrm{PGI}_{2}$ 生成阻害活 性の低い代謝物として存在することが示唆され た. なた，毎投与 24 時間後の $\mathrm{TXB}_{2}$ 濃度は初回
投与後 24 時間後の $\mathrm{TXB}_{2}$ 濃度と変化なく, 連投 による薬効の変化（増強または減弱）はないと推 察された。

4）非絶食雄性マウスに $2 \mathrm{mg} / \mathrm{kg}$ 反復経口投 与した際, 尿, 䔬中への排泄は投与回数に伴う变 化は認められず，21回投与後120時間まで尿中に は累積投与量の $1.3 \%$ ，糞中には $92.7 \%$ が排泄さ れた.

5）非絶食雄性マウスに KBT-3022を $2 \mathrm{mg} /$ $\mathrm{kg}$ 反復経口投与し, 各酵素活性を調べたところ, 肝薬物代謝酵素活性は vehicle 群と比較して差は 認められなかった。

\section{文献}

1）世古典彦, 吉野公一郎, 横田耕一, 山下 明, 伊 藤敬三，塚本悟郎：血小板凝集阻害作用を有する 新規ジフェニルアゾール誘導体の合成とその構造 活性相関. 第 9 回メディシナルケミストリーシン ポジウム講演要旨集, p. 131 (1988); Yokota, K., Yamamoto, N., Morimoto, Y., Yamashita, A. and Ito, K.: Anti-platelet activity of KB-3022. Jpn. J. Pharmacol., 46 (Suppl.): p. 190 (1988).

2) 中田雄一郎, 三宅美穂, 嶋田 斎, 藤川真章, 粟田 則男, 畔取政行, 荒川勝雅, 市毛一美, 堀 勝行 : 新規抗血小板薬 Ethyl 2-[4,5-bis (4-methoxyphenyl) thiazol-2-yl]pyrrol-1-ylacetate (KBT-3022) のマ ウスに打ける単回経口投与時の吸収, 分布, 排泄. 薬物動態 9, 209-220 (1994).

3) 久米章司, 桜井兵一郎, 新村浩一, 高畑京也: プ ロスタサイクリンの測定. 臨床検査, 27: 136143 (1983).

4) Matsubara, T., Yoshihara, E., Iwata, T., Tochino, Y. and Hachino, Y.: Biotransformation of coumarin derivatives (1), 7-alkoxycoumarin O-dealkylase in liver microsomes. Jpn. J. Pharmacol., 32: 921 (1982).

5) Lowry, O. H., Rosebrough, N. J., Farr, A. L. and Randall, R. J.: Protein measurement with the Folin phenol reagent. J. Biol. Chem., 193: 265-275 (1951).

6) Omura, T. and Sato, R.: The carbon monoxidebinding pigment of liver microsomes. J. Biol. Chem., 239: 2370-2378 (1964).

7) Matsubara, T., Touchi, A. and Tochino, Y.: Hepatic aminopyrine N-demethylase system: Further studies of assay procedure. Jpn. J. Pharmacol., 17: 127-136 (1977).

8) Imai, Y., Ito, A. and Sato, R.: Evidence for biochemically different types of vesicles in the 
hepatic microsomal fraction. J. Biochem., 60: 417428 (1966).

9) Netter, K. J. and Seidel, G.: An adaptively stimulated O-demethylating system in rat liver microsomes and its kinetic properties. J. Pharmacol. Exp. Ther., 146: 61-65 (1964).

10) Isselbacher, K. J., Chrabas, M. F. and Quinn, R. C.: The solubilization and partial purification of a glucuronyl transferase from rabbit liver micro- somes. J. Biol. Chem., 237: 3033-3036 (1962).

11）鹿取 信 : アラキドン酸代謝を中心とした血小板 の脂質代謝. 医学のあゆみ, 114: 577-584 (1980).

12）中田雄一郎, 三宅美穂, 藤川真章, 谷沢利恵, 粟田 則男, 畔取政行 : 新規抗血小板薬 Ethyl 2-[4,5-bis (4-methoxyphenyl) thiazol-2-yl]pyrrol-1-ylacetate (KBT-3022) のマウス, ラット, イヌにおける薬 物動態の種差及び性差. 薬剂学, 53: 210-220 (1993). 